\title{
Parasite Communities of the Pacific Mole Crab, Emerita rathbunae (Anomura: Hippidae), in Sandy Beaches from Guerrero and Michoacán, Mexico
}

\author{
Juan Violante-Gonzalez', Guadalupe Quiterio-Rendon², Scott Monks², \\ Sergio García-Ibañez1, Griselda Pulido-Flores², Agustín A. Rojas-Herrera', \\ Edvino Larumbe-Moran ${ }^{3}$ \\ ${ }^{1}$ Unidad Académica de Ecología Marina, Universidad Autónoma de Guerrero, Acapulco, México \\ ${ }^{2}$ Centro de Investigaciones Biológicas, Universidad Autónoma del Estado de Hidalgo, Pachuca, México \\ ${ }^{3}$ Centro de Estudios Tecnológicos del Mar, Lázaro Cárdenas, México \\ Email: viojuang@yahoo.com.mx
}

Received 30 August 2015; accepted 24 October 2015; published 27 October 2015

Copyright (C) 2015 by authors and Scientific Research Publishing Inc.

This work is licensed under the Creative Commons Attribution International License (CC BY).

http://creativecommons.org/licenses/by/4.0/

(c) (i) Open Access

\section{Abstract}

The species composition and infection levels were determined for helminth parasites in the mole crab, Emerita rathbunae, collected from seven sandy beaches from Guerrero and Michoacán, México. A total of 494 crabs were collected between August and December of 2009. The number of crabs that were examined from each beach varied from 40 in Lázaro Cárdenas to 114 in El Revolcadero. The cephalothorax length varied significantly between the sampled beaches, from $32.9 \pm$ $5.5 \mathrm{~mm}$ (Ixtapa) to $40.5 \pm 1.7 \mathrm{~mm}$ (Las Trancas). Four species of larval parasites were identified: 1 metacercaria (Microphallus nicolli), 1 cystacanth (Profilicollis sp.), 1 cestode (Trypanorhyncha) and 1 nematode (Proleptus sp.). Infection levels (prevalence and mean abundance) varied significantly between beaches, due to possible differences in the availability of final or intermediate hosts in beaches visited by tourist and those beaches not visited by tourists, as well as the size of individual hosts. Helminth communities, at levels of component and infracommunity, were characterized by a low number of species ( 3 to 4 ) and a high dominance by the metacercaria of $M$. nicolli. The body size of the hosts was positively correlated with the number of parasites and species richness of helminths, indicating that larger crabs accumulate a higher number of parasites during the lifetime, and that they harbor a higher number of species of helminth than smaller crabs. 


\section{Keywords}

\section{Parasite Community, Emerita rathbunae, Hippidae, Mexican Pacific Coast}

\section{Introduction}

In natural populations of free living organisms, the infection levels of parasites differ among localities and seasons, providing a strong indication that the recruitment of parasites by the population of hosts is variable in time and in space [1]-[3]. Most of the studies carried out to date on temporal and spatial variation have been focused mainly on the population dynamics of trematodes. Those studies suggest that the variation in the infections levels of parasites is a consequence of several factors, such as host movement, population density, life history, susceptibility to infection and to the dispersion and behavior of the parasites [2] [4]-[7].

Temporal and spatial heterogeneity of helminths has been observed frequently in many populations of crustaceans as intermediate hosts [2] [3] [7]-[9]. Many types of intermediate hosts, such as crabs, are restricted to a relatively small locality compared to the wider area visited by the highly mobile definitive hosts, such as birds and marine fishes. The spatial heterogeneity in the parasite distribution observed among populations of intermediate hosts, has been attributed both to the higher mobility of the definitive hosts and to associated behavior patterns [2] [5] [6] [9].

Emerita rathbunae (Pacific sand crab, or mole crab) is a common inhabitant in the splash zone of sandy beaches in the intertidal zone, with a distribution restricted to the tropical region along the Pacific coast [10]. In addition to its importance as an ecological component of the invertebrate benthonic communities of sandy beaches, and as a prey item for fish (teleosts and elasmobranchs) and marine birds (Larus spp., Calidris sp., among others) [3], this crab is of economic importance in Guerrero, Mexico, because it is utilized for consumption locally in communities along the coast.

In Mexico, the parasite communities of E. rathbunae have not been studied. However, the parasites of Emerita have been reported from other localities in the American continent [8] [9] [11] [12], but it is unknown whether the same species parasitize these mole crabs in Mexico, and if the infection levels are constant, or if they vary between localities. Therefore, the aim of this study was to determine the species composition, and infection levels of the helminth parasites of E. rathbunae from several sandy beaches, along the Mexican Pacific coast as a first step in understanding the population dynamics of the helminths of this host.

\section{Material and Methods}

Samples of E. rathbunae (Table 1) were taken from seven sandy beaches, along about $300 \mathrm{~km}$ of the Pacific Coast of Guerrero and Michoacán States, Mexico, between August and December 2009. Six beaches are located in Guerrero: Barra Vieja (BV: $16^{\circ} 41^{\prime} \mathrm{N}, 99^{\circ} 37^{\prime} \mathrm{W}$ ), San Andrés (SA: $16^{\circ} 42^{\prime} \mathrm{N}, 99^{\circ} 40^{\prime} \mathrm{W}$ ), Revolcadero (RE: $16^{\circ} 47^{\prime} \mathrm{N}, 99^{\circ} 47^{\prime} \mathrm{W}$ ), Mogotes (MO: $16^{\circ} 56^{\prime} \mathrm{N}, 100^{\circ} 03^{\prime} \mathrm{W}$ ), Las Trancas (TR: $16^{\circ} 59^{\prime} \mathrm{N}, 100^{\circ} 13^{\prime} \mathrm{W}$ ), and Ixtapa (IX: $17^{\circ} 39^{\prime} \mathrm{N}, 101^{\circ} 36^{\prime} \mathrm{W}$ ). One beach is located in Michoacán: Lázaro Cárdenas (LZ: $17^{\circ} 57^{\prime} \mathrm{N}, 102^{\circ} 17^{\prime} \mathrm{W}$ ).

Crabs were captured by hand in each locality, placed in labeled plastic bags, and then frozen until dissection; for verification of the identity of the helminths, other individuals were collected and dissected immediately without freezing. Helminths for verification of identity and deposit as vouchers were processed according to Violante-González et al. [13]. Samples of snails that cohabited with the crabs, were taken from 2 beaches (Barra Vieja and San Andrés), to determine if they harbored trematode larvae that might be part of the life cycles of those inhabiting the crabs.

The cephalothorax length (C.L. \pm standard deviation in $\mathrm{mm}$ ) of 494 crabs was measured before each was dissected; this measure was considered as the standard size of the crabs in later analyses. For the dissection, the carapace was removed first, and then each one of the internal structures was examined: gills, heart, hepatopancreas, stomach, intestine, and muscle. Helminths found in each crab were quantified, and reference samples of all species were taken. The shells of snails were broken, and internal structures (gills, mantle, gonad, and digestive gland) were removed and examined. Voucher specimens of all helminths were deposited in the Colección Nacional de Helmintos (CNHE), Instituto de Biología, Universidad Nacional Autónoma de México, México City, México (CNHE-8301 to 8314). 
Species composition of the parasite populations were described using prevalence (percent of infected hosts), and mean abundance (mean number of parasites per host) for each species of helminth per beach. Possible differences in the infection parameters between beaches, were evaluated using G-tests [14] for prevalence, and a $\chi^{2}$ test for abundance.

Analyses were made at the levels of component community (i.e., total parasites in all hosts per beach) and infracommunity (i.e., total parasites in an individual host) [15]. Component community parameters included the total number of species of helminth, total number of individual helminths, the Shannon-Wiener Index $(\mathrm{H})$ as a measure of diversity, and the Berger-Parker Index (BPI) as a measure of numerical dominance [16]. Infracommunities were described in terms of mean number of species per host, mean number of individual helminths, and the mean Brillouin Diversity Index (H’) value per host.

Univariate and multivariate analysis (Principal Component Analysis, PCA), were used to identify differences in the infection levels of each species of parasite, and infracommunity parameters between beaches, considering the following predictor variables: beach morphodynamics, tourist influence, climatic season, and host size (C. L.). Based on beach morphodynamics, beaches were classified as reflective (slope $>10$ degrees, high surf and coarse sand: MO, TR), or dissipative (slope $<5$ degrees, low to moderate surf and fine sand: BV, SA, RE, IX, LZ). Beaches also were classified as tourist (RE, IX, LZ), and not tourist (BV, SA, MO, TR) in accordance with the relative number of visitors. Host samples were pooled based on the climatic seasons in which they were collected: rainy (August-October) or dry (November-December) for the temporal analysis.

For the confirmation of PCA results, a Multidimensional Scaling Analysis (MDS) was applied, using the Alternating Least Squared Scaling (ALSCAL) method, to represent in a geometric space the distances existent, between the set of predictor variables and the parasite abundance or the infracommunity parameters. To homogenize the variances, the variables were transformed by the maximum magnitude method. The S-stress and the coefficient of determination $\left(\mathrm{R}^{2}\right)$ values, were considered as measures of goodness of fit to the model.

\section{Results}

A total of 494 individuals of E. rathbunae were examined; the range in sample size was between 40 (Lázaro Cárdenas) and 114 (Revolcadero). Cephalothorax length varied significantly between beaches, from $32.9 \pm 5.5$ $\mathrm{mm}$ (Ixtapa) to $40.5 \pm 1.7 \mathrm{~mm}$ (Las Trancas) (Anova $\mathrm{F}_{6487}=76.3, \mathrm{P}<0.0001$ ) (Table 1). Four species of larval helminth were identified in the samples from the seven beaches: Microphallus nicolli (metacercaria), Profilicollis sp. (cystacanth), Trypanorhyncha (plerocercus), and Proleptus sp. (nematode).

The metacercariae of $M$. nicolli were prevalent in all of the sampled beaches (Figure 1), but mean abundance varied significantly, from $885.9 \pm 629.4$ (Ixtapa), and $3237.0 \pm 1622.8$ (Las Trancas) metacercariae per host $\left(\chi^{2}\right.$ $=3278.7, \mathrm{P}<0.05)$. Prevalence of the acanthocephalan, Profilicollis sp., (Figure 2) was between $15.8 \%(\mathrm{Re}-$ volcadero), and $64.7 \%$ (Trancas) $(\mathrm{G}=59.09, \mathrm{P}<0.05)$; in 4 beaches the percentages of infection were $\geq 50 \%$, and in 2 (Revolcadero and Lázaro Cárdenas) they were $<20 \%$ (Figure 2). Mean abundance ranged from $0.19 \pm$ 0.10 (Revolcadero) to $1.32 \pm 0.74$ (Barra Vieja) (Figure 2), although this difference was not significant among beaches $\left(\chi^{2}=7.2, \mathrm{P}>0.05\right)$. Cestode larvae (Trypanorhyncha) were present only in 5 beaches (Figure 3); the percent infection varied significantly from $12.28 \%$ (Revolcadero) to $70.97 \%$ (Las Trancas) $(G=71.5, P<0.05)$. Mean abundance ranged from $0.12 \pm 0.01$ (Revolcadero) to $1.74 \pm 0.71$ (Las Trancas) (Figure 3), but differences in variation were not significant between beaches $\left(\chi^{2}=1.6, \mathrm{P}>0.05\right)$. Prevalences of the nematode Proleptus sp. (1.54\% at Lázaro Cárdenas to $91.94 \%$ at Las Trancas) (Figure 4) were significantly higher in San Andrés and Las Trancas beaches $(\mathrm{G}=180.49, \mathrm{P}<0.05)$. Mean abundance values (Figure 4$)$ of this species varied significantly between 0.03 (Ixtapa and L. Cárdenas) and $4.7 \pm 4.04$ (San Andrés) nematodes per host. The prevalence and abundance values of the Profilicollis sp., the trypanorhyncha, and Proleptus sp. were positively correlated $(\mathrm{P}<0.05)$, indicating that in the beaches in those species of helminths that were more prevalent also were more abundant. The snails, Agaronia testacea (mean length $20.6 \pm 3.2$, mean wide $=8.57 \pm 1.44 \mathrm{~mm}$, $\mathrm{n}=127$ ), that were cohabiting with E. rathbunae in Barra Vieja and San Andrés beaches, were positive for cercarial infection (prevalence of $42 \%$ ).

The PCA analysis, using the predictor variables of beach morphodynamics, tourist influence, climatic season, and host size, excluded the climatic season from the analysis. The resulting model, strongly suggests that not tourist and with low slope beaches (dissipative beaches) as Barra Vieja and San Andres, have larger crabs, and that as intermediate hosts, the larger individuals will have higher abundances of each of the species of parasites that were found (Table 2, Figure 5). Eigenvalues for the first two factors were 3.016 and 0.984 respectively, 

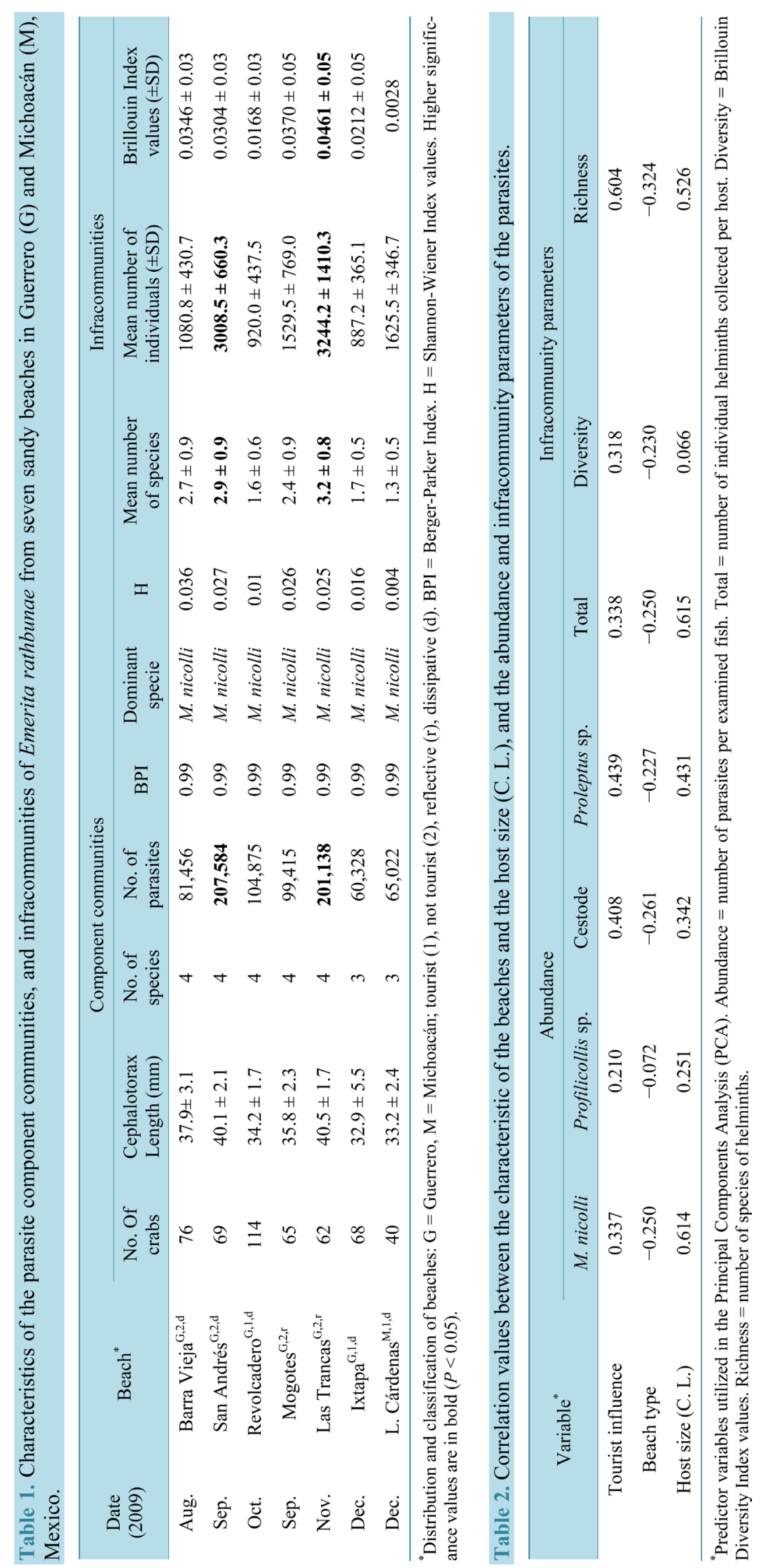


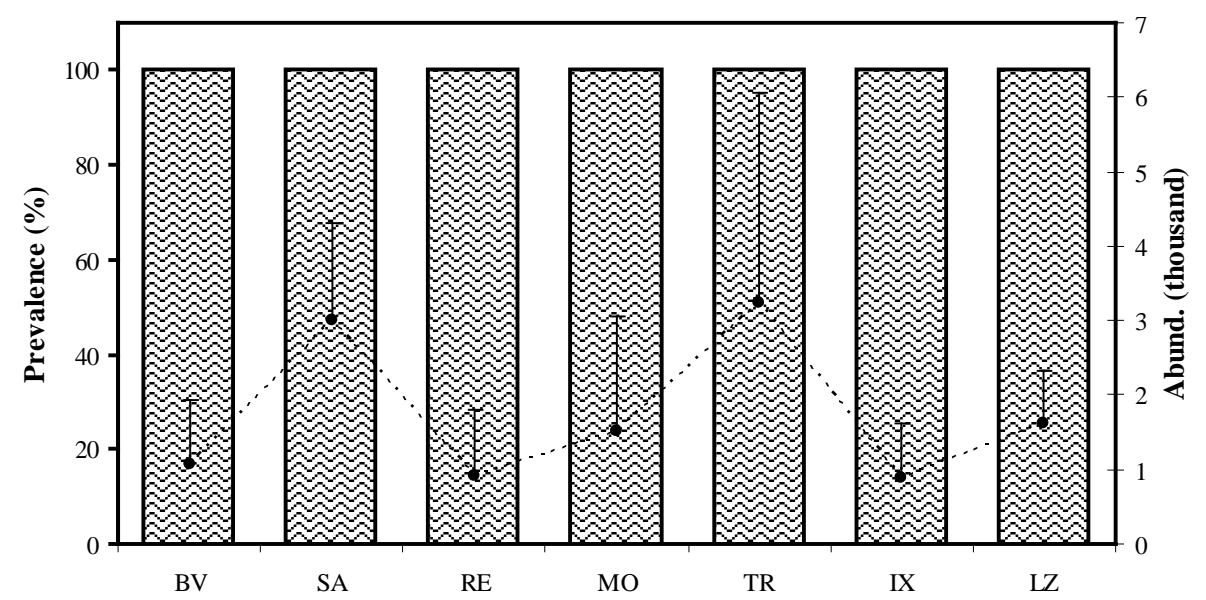

Figure 1. Infection parameters of helminths in the mole crab Emerita rathbunae from seven sandy beaches of Guerrero and Michoacán, Mexico (Prevalence = bars, Abundance = dotted lines). Microphallus nicolli (abundance in thousands). Locality codes: $\mathrm{BV}=$ Barra Vieja, SA $=$ San Andrés, RE $=$ Revolcadero, $\mathrm{MO}=$ Mogotes, $\mathrm{TR}=$ Las Trancas, IX = Ixtapa, LZ = Lázaro Cárdenas.

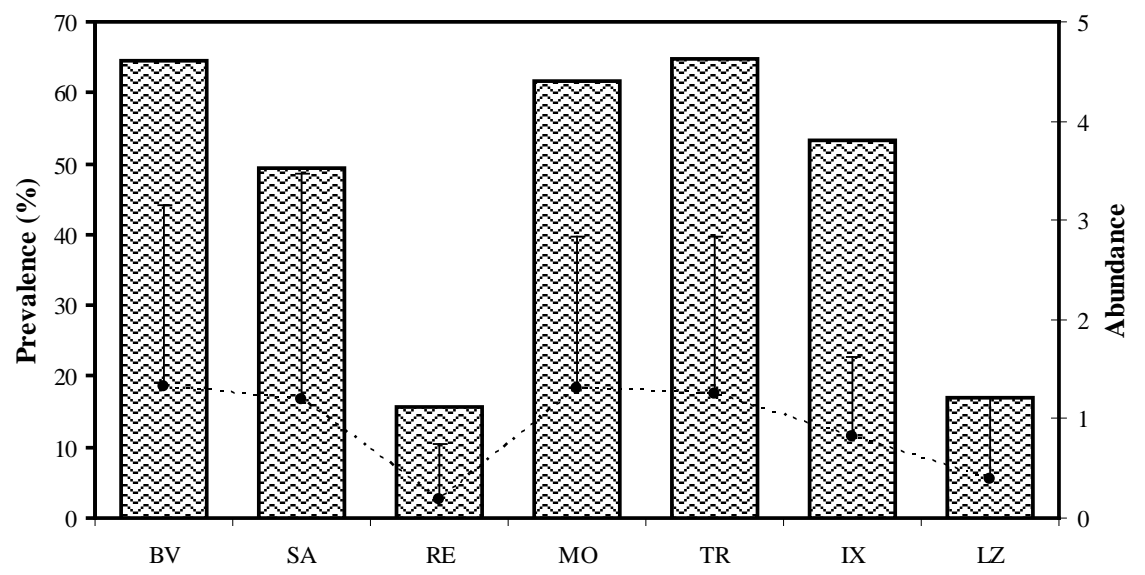

Figure 2. Infection parameters of helminths in the mole crab Emerita rathbunae from seven sandy beaches of Guerrero and Michoacán, Mexico (Prevalence = bars, Abundance $=$ dotted lines). Profilicollis sp. Locality codes: BV = Barra Vieja, SA = San Andrés, RE = Revolcadero, MO = Mogotes, TR = Las Trancas, IX = Ixtapa, LZ = Lázaro Cárdenas.

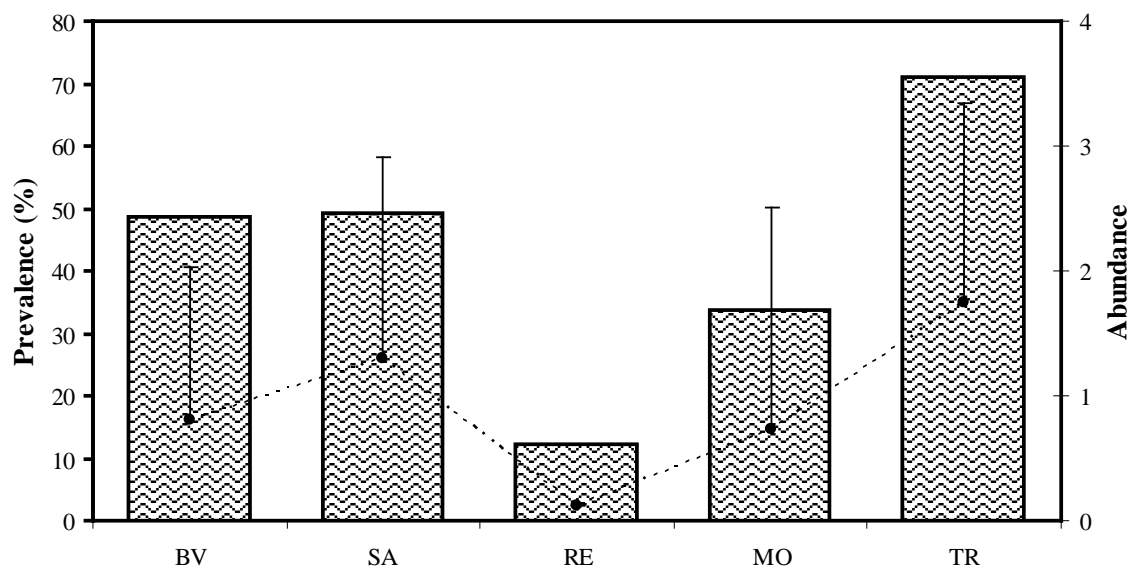

Figure 3. Infection parameters of helminths in the mole crab Emerita rathbunae from seven sandy beaches of Guerrero and Michoacán, Mexico (Prevalence = bars, Abundance = dotted lines). Trypanorhyncha. Locality codes: BV = Barra Vieja, SA = San Andrés, RE = Revolcadero, MO = Mogotes, TR = Las Trancas, IX = Ixtapa, LZ = Lázaro Cárdenas. 


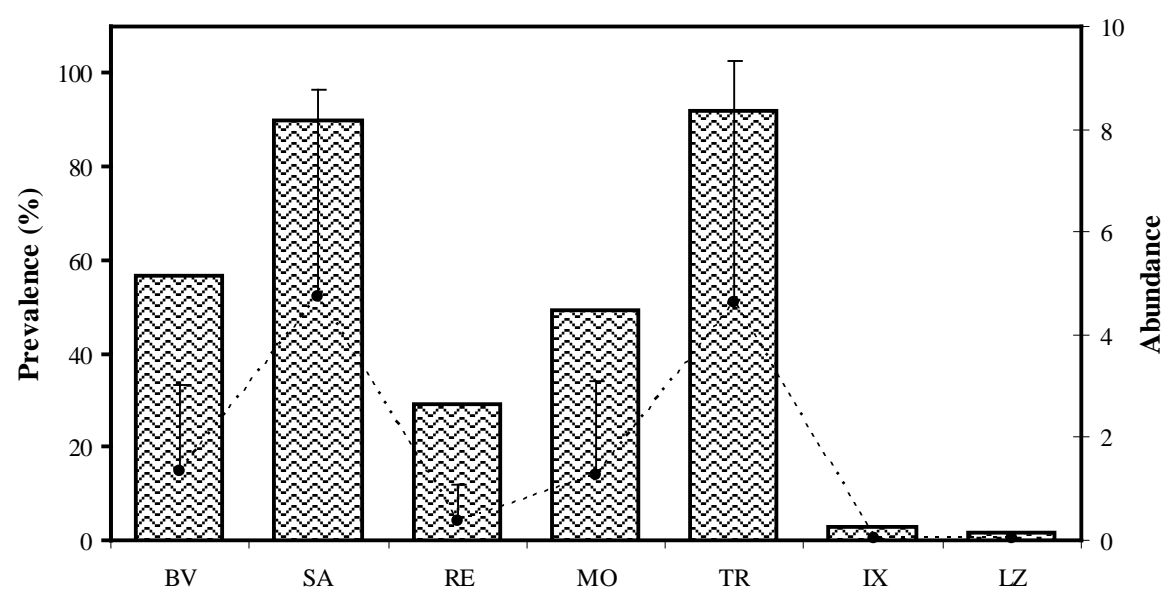

Figure 4. Infection parameters of helminths in the mole crab Emerita rathbunae from seven sandy beaches of Guerrero and Michoacán, Mexico (Prevalence $=$ bars, Abundance $=$ dotted lines). Proleptus sp. Locality codes: BV = Barra Vieja, SA = San Andrés, RE = Revolcadero, MO = Mogotes, TR = Las Trancas, IX = Ixtapa, LZ = Lázaro Cárdenas.

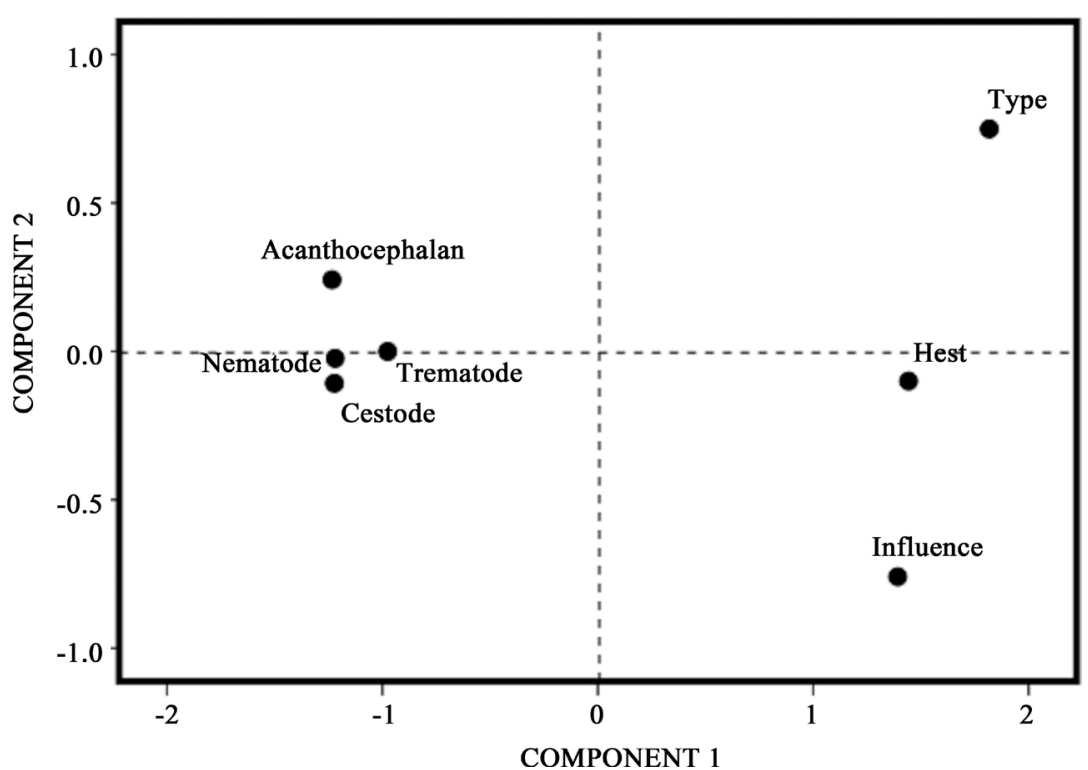

Figure 5. Variation of abundance of each species of helminth in the mole crab, Emerita rathbunae, using the characteristics of sandy beaches and the body size of crabs as predictor variables. Influence = tourist or not tourist beach; Type = reflective or dissipative beach; Host = body size of crabs.

and the total cumulative variance explained by the model was $43.091 \%$.

Species richness in the 7 populations of crabs from each beach, ranged from 3 to 4 species (Table 1). Total number of individual helminths (parasite load) varied significantly between 60,328 (Ixtapa) and 207,584 individuals (San Andrés) $(\mathrm{P}<0.05)$. Microphallus nicolli was the dominant species in all component communities, with values for the Berger-Parker Index (BPI) near unity (Table 1). Diversity values (Shannon-Wiener index) were very low (0.004 to 0.036$)$, and did not vary significantly among beaches $(\mathrm{P}>0.05)$.

The parasite infracommunities from San Andrés, and Las Trancas had the highest species richness (2.9 and 3.2, respectively) (Ancova $\mathrm{F}_{6486}=21.15, \mathrm{P}<0.05$ ), and the highest number of individuals parasites $(207,584$ and 201,138; respectively) (Ancova $\mathrm{F}_{6486}=15.2, \mathrm{P}<0.05$ ) (Table 1). A PCA analysis indicated a conclusion similar to the one registered by the previous analysis; i.e., the larger crabs collected from not tourist, and dissipative beaches had infracommunities with a higher mean number of parasites, and they were richer and more diverse (Table 2, Figure 6). In this second model, the eigenvalues were 2.89 and 1.36 for the first two factors, and the total cumulative variance explained was $70.87 \%$. 


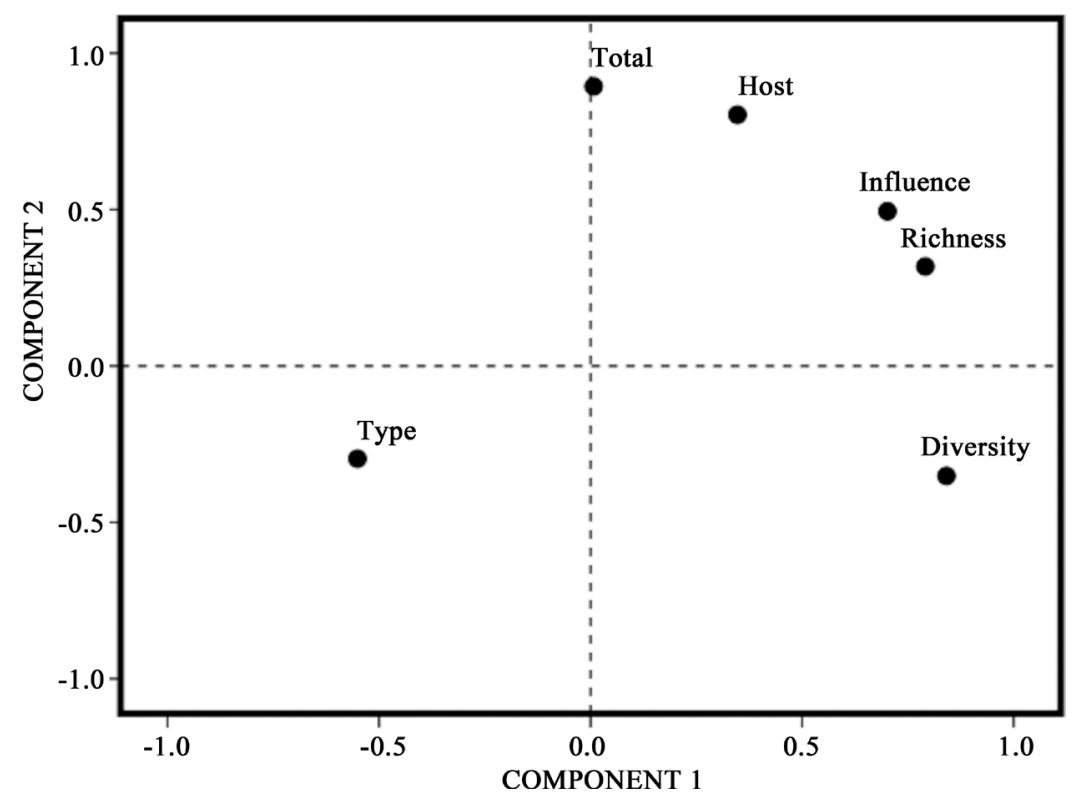

Figure 6. Variation of helminth infracommunity parameters in the mole crab, Emerita rathbunae, using the characteristics of sandy beaches and the body size of crabs as predictor variables. Influence = tourist or not tourist beach; Type = reflective or dissipative beach; Host = body size of crabs. Infracommunity parameters: Total = number of individual helminths per host; Richness = number of species; Diversity = brillouin diversity index values.

\section{Discussion}

The four species of helminth (Microphallus nicolli, Profilicollis sp., Proleptus sp. and Trypanorhyncha) are new geographical records for E. rathbunae in the states of Guerrero and Michoacán, in Mexico. Variation in the component community of parasites of Emerita analoga, another mole crab that inhabits the Pacific coasts of North, and South America has been reported [3] [8] [9] [12], and species composition varied regionally. Iannacone et al. [12] reported 7 species in E. analoga from Peru coasts, and Smith [9] found only 4 species in crabs from the coast of California. The results presented herein, are more similar to those obtained in California for $E$. analoga, which is geographically nearer with beaches comparable to Mexico.

In accordance with the existent information, the metacercariae of M. nicolli, and the cystacanth of Profilicollis sp. mature in coastal birds [9] [12], while larvae of the nematode Proleptus sp., and the trypanorhyncha cestode use marine fish as final host [8] [11] [12]. During sampling in the beaches of Barra Vieja and San Andrés, coastal marine birds (Catoptrophorus semipalmatus and Numenius phaeopus) were observed feeding actively on individuals of $E$. rathbunae. Based on these observations, we hypothesize that these species, among others, to be the final hosts for Profilicollis sp. and M. nicolli, as reported in other localities [9] [12]. Adults of Proleptus sp. have been reported from Pacific Coast elasmobranchs [17] [18] and tryphanorhynchs have been reported from stingrays collected along Mexican coasts [19]-[21].

The infection levels of the four species of helminth parasitizing E. rathbunae, varied significantly between beaches (Figures 1-4). Temporal and spatial variations in the infection levels of parasites in their intermediate host, are patterns commonly observed in studies of parasite ecology [2] [3] [7] [9] [22]. Spatial variation registered in infection levels, can be attributed to the presence of larger crabs in beaches not visited by tourists (Table 1), as suggested by PCA analysis (Figure 5). The positive correlations registered between the size of crabs, and the number of helminths per crab (Table 2), suggests that they accumulate parasites during their lives, which can be up to 3.5 years [3].

Some beaches, such as El Revolcadero, Ixtapa and Lázaro Cárdenas, are visited more frequently by tourists, and casual observations suggest that this influences the presence of marine birds, that are the final hosts by allogenic helminths (i.e., M. nicolli and Profilicollis sp.). For example, the mean abundance of M. nicolli was significantly lower in the first two of these beaches (Figure 1), while the abundance of Profilicollis sp. and Proleptus sp. was lower in the three beaches, all considered as tourist beaches (Figure 2, Figure 4). It is interesting that these 2 groups of helminth both use this same intermediate host, but their definitive hosts are completely 
different (aquatic vertebrates, and birds); these relationships must be studied further.

Spatial and temporal differences in the population abundance of the first intermediate hosts, also could be a possible cause of the variation in the infection levels in E. rathbunae [9] [12]. The snail Agaronia testacea was cohabiting with the crabs in two of the beaches (Barra Vieja and San Andrés) not frequented as often by tourists. The life cycle of M. nicolli has not been studied in Mexico, but this snail was positive to the infection for cercariae, and might serve as first intermediate host for this species. Variation in the abundance of the snail in each beach could be a contributing factor. Smith [9] pointed out that a snail of the same family, Olivella biplicata (Olividae), serves as first intermediate host of Microphallus nicolli (reported as Spelotrema nicolli) in the coasts of California, and suggested that these snails also could have seasonal infection patterns.

The parasite communities of $E$. rathbunae were characterized by low species richness ( 3 to 4 species) and diversity, and they were highly dominated by the metacercaria of $M$. nicolli at both study levels (component, and infracommunity) (Table 1). Alvitres et al. [8], in a study of E. analoga in northern Peru, found a more rich community (7 species), than those studied herein. In contrast, Iannacone et al. [12], in another study in Peru reported only 3 species, and Smith [9] also reported 3 helminth species; results from both latter studies are similar to those found in the current study.

The numeric dominance of the trematode $M$. nicolli in the parasite communities of E. rathbunae, has been also documented in other localities for E. analoga [8] [9]. Thieltges et al. [23], using published studies of trematode infections in crustaceans, concluded that these helminths were the dominant parasites in interstitial systems, being transmitted by their first intermediate host (snails) to a wide range of second intermediate hosts, including crustaceans. These same authors suggest that the species richness of trematodes in crustaceans, is generally low ( 1 to 2 species), and infection levels are, in most of cases, moderate (prevalence $<10 \%$, and mean abundance $<$ 5 parasites per infected host). In this sense, the infection levels of $M$. nicolli (prevalence $=100 \%$, mean abundance $=900$ - 3000 cysts per host, Figure 1) that we found are notable. However, as mentioned above, knowledge to date is insufficient even to hypothesize whether the relatively high parasite load seen in this study is out of the ordinary, or if the high number of individuals causes a negative affect on the mortality of the crabs.

\section{Conclusion}

From our results, we can conclude that differences in the sizes of crabs, is directly related to differences in the populations of their helminths. Although more study is needed, we suggest that the availability of final and intermediate hosts, is negatively affected by the presence of tourists on the beaches that we studied, and, finally, the presence of tourists is an indirect cause of the variation in the parasite infection levels in E. rathbunae.

\section{Acknowledgements}

Funds for this were provided by the Programa de Mejoramiento del Profesorado (PROMEP) as part of the collaborative project "Red temática de colaboración: Calidad ambiental y desarrollo sustentable; Inventario ambiental y establecimiento de indicadores regionales”, of which all authors participated. Other funds were provided to JV-G through the project "Parásitos del chiquilique Emerita rathbunae y su posible repercusión en la salud pública”, financed by the Universidad Autónoma de Guerrero, and Fomix Conacyt-Guerrero 2015. The authors wish to thank to students of the Marine Ecology Academic Unit (UAG), for their assistance with field and laboratory work and local residents who assisted with collection of the crabs. The Consejo Nacional de Ciencia y Tecnología (CONACyT) provided a scholarship (No. 247514) to GQ-R.

\section{References}

[1] Sousa, W.P. (1990) Spatial Scale and the Processes Structuring a Guild of Larval Trematode Parasites. In: Esch, G.W., Bush, A.O. and Aho, J.H., Eds., Parasite Communities: Patterns and Processes, Chapman and Hall, London, 41-67. http://dx.doi.org/10.1007/978-94-009-0837-6_3

[2] Latham, A.D.M. and Poulin, R. (2003) Spatiotemporal Heterogeneity in Recruitment of Larval Parasites to Shore Crab Intermediate Hosts: The Influence of Shorebird Definitive Hosts. Canadian Journal of Zoology, 81, 1282-1291. http://dx.doi.org/10.1139/z03-118

[3] Oliva, M.E., Barrios, T., Thatje, S. and Laudien, J. (2008) Changes in Prevalence and Intensity of Infection of Profilicollis altmani (Perry, 1942) Cystacanth (Acanthocephala) Parasitizing the Mole Crab Emerita analoga (Stimpson, 1857): An El Niño Cascade Effect? Helgoland Marine Research, 62, 57-62. 
http://dx.doi.org/10.1007/s10152-007-0082-7

[4] Mouritsen, K.N., Jensen, T. and Jensen, K.T. (1997) Parasites on an Intertidal Corophium-Bed: Factors Determining the Phenology of Microphallid Trematodes in the Intermediate Host Populations of the Mud-Snail Hydrobia ulvae and the Amphipod Corophium volutator. Hydrobiologia, 355, 61-70. http://dx.doi.org/10.1023/A:1003067104516

[5] Marcogliese, D.J. (2001) Pursuing Parasites up the Food Chain: Implications of Food Web Structure and Function on Parasite Communities in Aquatic Systems. Acta Parasitologica, 46, 82-93.

[6] Smith, N.F. (2001) Spatial Heterogeneity in Recruitment of Larval Trematodes to Snail Intermediate Hosts. Oecologia 127, 115-122. http://dx.doi.org/10.1007/s004420000560

[7] Studer, A. and Poulin, R. (2012) Seasonal Dynamics in an Intertidal Mudflat: The Case of a Complex Trematode Life Cycle. Marine Ecology Progress Series, 455, 79-93. http://dx.doi.org/10.3354/meps09761

[8] Alvitres, V., Chanamé, J., Fupuy, J., Chambergo, A. and Cortez, M. (1999) Cambios en la prevalencia de los helmintos parásitos de Emerita analoga por efecto de “El niño 1997-98”. Revista Peruana de Biología, 1, 69-76.

[9] Smith, N.F. (2007) Associations between Shorebird Abundance and Parasites in the Sand Crab, Emerita analoga, along the California Coast. Journal of Parasitology, 93, 265-273. http://dx.doi.org/10.1645/GE-1002R.1

[10] Tam, Y.K., Kornfield, I. and Ojeda, F.P. (1996) Divergence and Zoogeography of Mole Crabs, Emerita spp. (Decapoda: Hippidae), in the Americas. Marine Biology, 125, 489-497.

[11] Oliva, M.E., Luque, J. and Cevallos, A. (1992) Parásitos de Emerita analoga (Stimpson) (Crustacea): Implicancias ecológicas. Boletín de Lima, 79, 77-80.

[12] Iannacone, J., Alvariño, L. and Bolognesi, B. (2007) Aspectos cuantitativos de los metazoos parásitos del muy muy Emerita analoga (Stimpson) (Decapoda, Hippidae) en Chorrillos, Lima, Perú. Neotropical Helminthology, 1, 1-2.

[13] Violante-González, J., Monks, S., Gil-Guerrero, S., Rojas-Herrera, A. and Flores-Rodríguez, P. (2012) Helminth Communities of Two Species of Piscivorous Birds, Ardea alba (Linnaeus) and Nyctanassa violacea (Gmelin) (Ciconiiformes: Ardeidae), in Two Coastal Lagoons from Guerrero State, Mexico. Parasitology Research, 111, 309-315. http://dx.doi.org/10.1007/s00436-012-2840-y

[14] Sokal, R.R. and Rohlf, F.J. (1998) Biometry. 2nd Edition, W. H. Freeman and Company, San Francisco, 859 p.

[15] Holmes, J.C. and Price, P.W. (1986) Communities of Parasites. In: Anderson, D.J. and Kikkawa, J., Eds., Community Ecology: Patterns and Processes, Blackwell Scientific Publications, Oxford, 187-213.

[16] Magurran, A. (2004) Ecological Diversity and Its Measurement. Princeton University Press, Princeton, 178 p.

[17] Dailey, M.D. and Carvajal, J. (1976) Helminth Parasites of Rhinobatos planiceps Garman 1880, Including Two New Species of Cestodes, with Comments on Host Specificity of the Genus Rhinebothrium Linton 1890. Journal of Parasitology, 62, 939-942. http://dx.doi.org/10.2307/3279187

[18] Muñoz, G. and Olmos, V. (2008) Revisión bibliográfica de especies endoparásitas y hospedadoras de sistemas acuáticos de Chile. Revista de Biología Marina y Oceanografía, 43, 173-245.

[19] Cruz-Reyes, A. (1973) Céstodos de peces de México. I. Redescripción del subgénero Otobothrium (Pseudotobothrium) (Dollfus, 1942) y de la especie Otobothrium (P.) dipsagun (Linton, 1807). Anales del Instituto de Biología. UNAM, 44, 25-34.

[20] Campbell, R.A. and Beveridge, I. (1997) Pterobothrioides, a New Genus of Tapeworms (Cestoda: Trypanorhyncha: Pterobothriidae) from Dasyatid Stingrays in the Eastern Atlantic and Pacific Oceans. Systematic Parasitology, 38, 8191. http://dx.doi.org/10.1023/A:1005805005267

[21] Campbell, R.A. and Beveridge, I. (2006) Two New Species of Pseudochristianella Campbell \& Beveridge, 1990 (Cestoda: Trypanorhyncha) from Elasmobranch Fishes from the Gulf of California, Mexico. Parasite, 13, 275-281. http://dx.doi.org/10.1051/parasite/2006134275

[22] Latham, A.D.M. and Poulin, R. (2002) Field Evidence of the Impact of Two Acanthocephalan Parasites on the Mortality of Three Species of New Zealand Shore Crabs (Brachyura). Marine Biology, 41, 1131-1139.

[23] Thieltges, D., Fredensborg, B., Studer, A. and Poulin, R. (2009) Large-Scale Patterns in Trematode Richness and Infection Levels in Marine Crustacean Hosts. Marine Ecology Progress Series, 389, 139-147. http://dx.doi.org/10.3354/meps08188 